\title{
Composition of High Order Thinking Skill in English Course Book for the Tenth Grade of Senior High School in Indonesia
}

\author{
Syamsul Ibrar ${ }^{1 *}$, Mukhaiyar ${ }^{2}$
}

\author{
${ }^{1 *}$ Universitas Negeri Padang, Padang, 25131, Indonesia \\ ${ }^{2}$ Faculty of Languages and Arts, Universitas Negeri Padang, Padang, 25131, Indonesia \\ ${ }^{*}$ Corresponding author. Email $\square$ samsulibrar@gmail.com
}

\begin{abstract}
This research describes the composition of HOTs in reading exercises of English course book for 10th grade senior high school published by the ministry of education and culture based on the Bloom's Taxonomy. This research is a descriptive. The data was collected through several instruments, namely English Course Book, analysis card, and checklist table. This research showed that there were four types of reading exercises: essay, matching, short-answer, and completion. The result of the distribution of HOTs are analyse skills, 33 of 171 questions $(19,3 \%)$, evaluating skills get 10 out of $171(5,8 \%)$, and create skills, 5 of $171(3 \%)$. The types of reading exercises found are varied and dominated by essay and the distribution of HOTs among them only $28,07 \%$. It means, the distribution is unequal since the composition of LOTs is far if it is compared to the range of total score and the ratio.
\end{abstract}

\section{Keywords: English Course Book, High Order Thinking Skill, Reading Exercises,}

\section{INTRODUCTION}

Critical thinking ability becomes one of the issue arised by the Indonesian government recently. It is aimed to prepare the students to compete globally, as a result the process of teaching and learning becomes more interesting and challenging especially in teaching and learning English subject. In order to achieve that goal, the teaching and learning English should well prepared, especially in teaching material or the textbook that is appropriate for the needs of students nowadays. Teacher has to tactful to select a proper course book. In material book, many aspects need to be evaluated. Teacher must examine the variation of exercises, whether the material has practiced the skill of basic language and support the purpose of 2013 curricullum. The English course book which is published the Ministry of Education and Culture, additionally, is one of favorite English teachers in Senior High School of Padang city. But in fact, there is no evaluation whether this book obtains the exercise the high order thinking skill or not.

This emptiness become the basis of the research conducted. It is important to be done remembering that the education system must be improved in the framework of producing an adequate education quality both nationally and globally. The global needs of the 21 st century directly give challenge to the education system in Indonesia. One of them is to prepare students with real life skills that will enable them to be relevant individuals who are capable of creativity and innovative skills to compete internationally.
In order to achieve that goal, developing students' critical thinking skills is necessary. According to Partnership (2009) critical thinking has been identified as one of the $21^{\text {st }}$ century skills students need to be developed in order to succeed in modern society. In conclusion, having critical thinking ability is necessary for students especially in this millenial era.

Apart from being one of the most modern issues in education around the world (Sanavi and Tarighat, 2014), critical thinking has long been acknowledged as a valuable skill, both in education and within the world of English language teaching in particular. In short, critical thinking is recognized as an important competence for students to acquire in academic language (Conolly, 2000). In order to develop students' critical thinking ability the teachers have to be able to stimulate the process of students thinking by using an appropriate model of teaching and one of them is giving the HOTS questions or High Order Thinking Skill questions. However, in reality this has not been done well. On monitoring the supervision and guidance of Post-High School Learning Achievement Evaluation conducted by the Directorate of High School Development in 2015, most of high school teachers in compiling items of assessment tend to only measure low order thinking. The previous research that has been done by Sardareh, etc (2014) also pointed out that Malaysian English language teachers tend to utilize only lower order questions and this was attributed to their lack of skills in using questions that were more challenging. Besides, Fah (2010) also found 
that the level of thinking skills of students secondary school in Sabah was lower and lack of skills needed to critically read and understand English language reading text. Based on this explanation, the critical thinking of students is still low and lack of practice by using high order thinking questions. It is caused the teachers and the material used in the low category of questions as a result the students critical thinking is still difficult to be achieved.

Moreover, teachers is not only the core of education, but also material of teaching such as textbook is one of the important tool in the process of success in learning English language. Richards (2001) stated, even nowdays the advances of technology era, text books still become important in language's learning and teaching in which it provides a helpful resource to student, teacher and also as an official guideline to organize the process of learning. With this argument, textbooks have to adequate in education world. Iqbal (2013) also stated that the existence of textbooks was able to facilitate students in achieving the objectives of learning targeted. Hence, textbook is one of the learning sources that is necessary for students in guiding and developing their ability in English language learning so that the quality of textbook should be able to increase students' achievements.

The quality of book is influenced the students' motivation and achievements in teaching and learning process. Therefore, the teachers must check the existence of exercise variations in the course book, In textbook, exercise gives important role because it will help the pupil practicing competence and getting good result in the process of learning. For the student of Indonesia that study English, reading is not easy to be learned. As Harmer (1996) stated, reading skill is hard because there are elaborate skills in reading.

Anyhow, Keshta \& Seif (2013) also explain that the skill of reading comprehension must be provided beside all cognitive skills (consist of the ability to recall the schemata information, comprehend, apply, analyse, synthesize, and evaluate). Marier (2002) also affirms that students should be taught how to read in order to become effective readers. In order to fulfil this aspect, good readers use higher order thinking strategies to think about, and control their reading before, during, and after reading selection.

Furthermore, HOTS in Bloom's taxonomy consist of three they are analyse, evaluate, and create. It is regarded as a usepful instrument. HOTS in the process of learning could improve the ability of students in critical thinking skill to evaluate information, and this skill is really important to prepare to do their own thinking in the reality ('Ilma, 2018). In the 2013 curriculum itself, there are 5 scientific approaches in the learning process (observe, question, association, experiment, and network). Suharyadi (2014) states, in the observing, students are able to attribute what they've learned and what they will be learned. The second and third aprroach, are able to helpful in developing student's critical thinking in process of thinking. The fourth approach, is able to assit the pupil in problem solving they face. And the last, enable the pupil in facing all the changes and the challenges to be learned. It concluded that the scientific approach in the 2013 curriculum are related to HOTS, therefore all of aspects and material in teaching English should engage students' critical thinking by exercise it with higher order thinking skill.

Research in textbooks evaluation of HOTS has been done by some researchers, such as math, science, language books and even in social studies (Keshta \& Seif, 2013). Based on the previous research that they have been done in Palestine, only $46 \%$ of the English textbook covered the HOTS reading exercises. The findings, by the Palestinian Ministry of Higher Education found thet the general objectives of teaching English are not matched. In Indonesia itself, 'Ilma (2018) evaluated junior high school course book showed that the HOT distributions gained eight from thirty-three questions is "analyzed", and the most dominant exercise is short-answer questions. The findings of these research can be stated that the HOT skills are still a discourse that have no effort to be appeared seriously. Damanik and Zainil (2019) revealed on their research that mostly-used HOTS criteria in reading question comprehension in English text material at grade $\mathrm{x}$ of SMAN 2 padang Indonesia by using HOTS is analyzing category. The knowledge aspect found in the questions are factual knowledge, conceptual knowledge, procedural knowledge, and metacognitive knowledge. As a result, 36 questions $(9.7 \%)$ HOTS questions in reading comprehension questions were found.

In Padang city, the English teachers of Senior High Schools use this book as a first or second book. They argue that the main reason of using this because it mandates by the government and it is in line with the 2013 curriculum. The book is easier to get because available in the internet. The content of the book is also clear and complete. In addition, the material presented well and the exercises include four skills in English. On the other hands, the English language book issued by ministry of education and culture is one of the book that is widely used by teachers in teaching but there is no explanation in them whether the book is intended to improve students' critical thinking skills. Seeing the importance of high order thinking skills in the reading exercisess in improving students' thinking abilities and book as the basis of these achievements, this study is aimed to examine the HOTS distributions in exercises of reading of course book published by Indonesia ministry of education and culture. The purpose of this study is describe the composition of the HOTS in reading exercises of English books for 10th grade senior high school published by Indonesia ministry of education and culture. The specific purposes are identified types of reading exercises and analyze the distribution of the HOTS in the reading exercise in that book.

\section{METHOD}

This research was categorized as a kind of descriptive research. The main purpose of descriptive research is to provide an accurate description or picture of 
the status, characteristics of a situation or phenomenon (Johnson \& Christensen, 2012). Particularly, it is focused on describing the variables that exist in a given situation and sometimes on describing the relationship that exists between those variables. Besides, it also conducted to learn about attitudes, opinions, beliefs, behaviours, and demographic. This type of research determined and reported the way things are. It is in lined with the purpose of this research is to analyse the questions in reading exercises related to higher order thinking skill. Specifically, the researcher figured out the types of reading exercises and the contribution of higher order thinking skill questions in that represented in the course book published Indonesia ministry of education and culture. There were two data sources used in this research, the English course book for $10^{\text {th }}$ grade published by ministry of education and culture and analysis checklist. The key instrument was the researcher since the researcher involved directly in the process of research. In addition, the instrument used in this research is the analysis checklist. This instrument was decided to use based on the consideration that by using those instruments, the data were possibly retrieved comprehensively and representatively.

The analysis checklist was used as a reference to decide what kind of reading exercise and distribution of reading exercises used HOT skill questions represented in course book that is published by Indonesia Ministry of Education and Culture. The indicators in analyzing reading exercises are adopted from theory Crawley \& Merrit (2003), meanwhile the higher order thinking skill questions are adopted from Bloom's taxonomy, revised edition, that is explained by Brookhart (2010). In order to make it to be clear, the detailed of indicators could be seen in table 1.

Table 1 Indicators of types of reading exercise and higher order thinking skill questions

Indicators Sub-indicators

$\begin{array}{lll}\text { Types of } & \text { 1. } & \text { Essay } \\ \text { reading } & \text { 2. } & \text { True or false } \\ \text { exercises } & \text { 3. } & \text { Matching } \\ & \text { 4. } & \text { Short answer } \\ & \text { 5. } & \text { Multiple choice } \\ & \text { 6. } & \text { Completion item }\end{array}$

$\begin{array}{ll}\text { Types of } & \text { Low order thinking skill questions } \\ \text { reading } & \text { 1. Remember } \\ \text { exercises } & \text { 2. Understand } \\ \text { questions } & \text { 3. Apply } \\ & \text { Higher order thinking skill questions } \\ & \text { 1. Analyze } \\ & \text { 2. Evaluate } \\ & \text { 3. Create }\end{array}$

There were several steps in collecting the data in this research. (1) Getting and distributing the document. In order to substitute the trustworthiness, the researcher asked the English teachers to analysis the document. The document in this research is reading exercises in English course book published by Indonesia Ministry of Education and Culture for Senior High School at the 10 grade. (2) Distributing analysis checklist by the analysts. Each of the analysts got the same form of analysis checklist. (3) Filling in the analysis checklist by the analysts by giving chekclist mark on the column yes/no or filling the note coloumn if there is any comment from the analysts related to indicators in the analysis checklist. In order to check the trustworthiness of the data (Creswell, 2003: 196), the researcher did some acts, they are: (1) Peer-debriefing, the researcher discussed with the peers, colleagues of the same interest and those who know and understand about HOTS questions in the reading material. In this phase, after classifying all the data, the researcher discussed the data with peer or colleagues to make sure the data are valid. (2) Auditing, the researcher discussed with the advisors about analysis and finding of data.The data analysis was conducted regarding the instrument that is used in this research. It was the analysis checklist. In analysing the data gotten from this instrument, there were some steps used as proposed by Gay and Arisian (2011: 468), they are: (1) Reading/Memoring. In this step, the analysis checklist gotten the analysts from were read and re-read for several times until the general information and understanding about the distribution of HOTS questions in reading exercises represented by English course book. (2) Describing. In this second step, the researcher described the data related to detail information about the type of reading exercises and distribution of higher order thinking skill questions represented by English course book for $10^{\text {th }}$ grade Senior High School. (3) Classifying. In explaining the data, the researcher classified the data of the analysis checklist into the types of reading exercises and distribution of higher order thinking skill questions represented by English course book for 10thgrade senior high school published by Indonesia ministry of education and culture are counted quantitatively. (4) Interpreting. This is the last step in analysing the data. It was used to get the conclusion and understanding about the research finding. The researcher interpreted the data qualitatively into three forms. (1) the data analysis related to the first, types of reading exercises; (2) reading exercise question types; and (3) distribution of HOTS questions in reading exercises.

\section{RESULT AND DISCUSSION}

There ae 15 chapters in this book. It is not only facilitating student with four basics of skill and language features namely vocabulary and grammar. Every chapter has different theme and topic. In reading texts, it can be classified to descriptive text, recount text, narrative text, announcement, dialogue, and song. Table 2 explains the distribution of reading exercises in English Course Book for $10^{\text {th }}$ grade. 
Table 2. The Distribution of Reading Exercises

\begin{tabular}{|c|c|c|c|}
\hline Chapter & Theme & $\begin{array}{c}\text { The } \\
\text { Exercises } \\
\text { in Every } \\
\text { Chapter }\end{array}$ & $\begin{array}{c}\text { The } \\
\text { Reading } \\
\text { Exercises }\end{array}$ \\
\hline 1 & $\begin{array}{l}\text { Talking about } \\
\text { Self }\end{array}$ & $\begin{array}{c}13 \\
\text { exercises }\end{array}$ & $\begin{array}{c}2 \\
\text { exercises }\end{array}$ \\
\hline 2 & $\begin{array}{l}\text { Congratulating } \\
\text { and } \\
\text { Complimenting } \\
\text { Others }\end{array}$ & $\begin{array}{c}17 \\
\text { exercises }\end{array}$ & $\begin{array}{c}3 \\
\text { exercises }\end{array}$ \\
\hline 3 & $\begin{array}{l}\text { Expressing } \\
\text { Intention }\end{array}$ & $\begin{array}{c}11 \\
\text { exercises }\end{array}$ & - \\
\hline 4 & $\begin{array}{l}\text { Which One is } \\
\text { Your Best } \\
\text { Getaway? }\end{array}$ & $\begin{array}{c}21 \\
\text { exercises }\end{array}$ & $\begin{array}{c}7 \\
\text { exercises }\end{array}$ \\
\hline 5 & $\begin{array}{l}\text { Let's Visit } \\
\text { Niagara Falls }\end{array}$ & $\begin{array}{c}12 \\
\text { exercises }\end{array}$ & $\begin{array}{c}3 \\
\text { exercises }\end{array}$ \\
\hline 6 & $\begin{array}{l}\text { Giving } \\
\text { Announcement }\end{array}$ & $\begin{array}{c}14 \\
\text { exercises }\end{array}$ & $\begin{array}{c}2 \\
\text { exercises }\end{array}$ \\
\hline 7 & $\begin{array}{l}\text { The Wright } \\
\text { Brothers }\end{array}$ & $\begin{array}{c}14 \\
\text { exercises }\end{array}$ & - \\
\hline 8 & My Idol & $\begin{array}{c}14 \\
\text { exercises }\end{array}$ & 1 exercise \\
\hline 9 & $\begin{array}{l}\text { The Battle of } \\
\text { Surabaya }\end{array}$ & $\begin{array}{c}13 \\
\text { exercises }\end{array}$ & $\begin{array}{c}2 \\
\text { exercises }\end{array}$ \\
\hline 10 & B.J. Habibie & $\begin{array}{c}13 \\
\text { exercises }\end{array}$ & $\begin{array}{c}2 \\
\text { exercises }\end{array}$ \\
\hline
\end{tabular}

\begin{tabular}{cccc}
\hline $\mathbf{1 1}$ & Cut NyakDien & $\begin{array}{c}11 \\
\text { exercises }\end{array}$ & $\begin{array}{c}2 \\
\text { exercises }\end{array}$ \\
\hline $\mathbf{1 2}$ & Issumboshi & $\begin{array}{c}16 \\
\text { exercises }\end{array}$ & $\begin{array}{c}3 \\
\text { exercises }\end{array}$ \\
\hline $\mathbf{1 3}$ & MalinKundang & $\begin{array}{c}13 \\
\text { exercises }\end{array}$ & 1 exercise \\
\hline $\mathbf{1 4}$ & Strong Wind & $\begin{array}{c}12 \\
\text { exercises }\end{array}$ & $\begin{array}{c}2 \\
\text { exercises }\end{array}$ \\
\hline $\mathbf{1 5}$ & You've Got a & 11 & - \\
& Friend & exercises & 205 \\
& Total & $\begin{array}{c}205 \\
\text { exerises }\end{array}$ & $\begin{array}{c}30 \\
\text { excises }\end{array}$ \\
\hline
\end{tabular}

There are 205 exercises as shown in table 2 and 30 exercises practice the skill of reading. 30 exercises exist with the type; Multiple Choice, Matching, True or False, Short Answer, , Completion Item and Essay. It means the distributions of reading exercise is the highest in English Course Book for $10^{\text {th }}$ grade Senior High School if compared with the other test types. Then, distribution of the types of test in reading exercises in course book can be explained in table 3 .

\section{Table 3. Reading Exercises Types}

\begin{tabular}{|c|c|c|c|c|c|c|}
\hline \multirow[t]{2}{*}{ Chapter } & \multicolumn{6}{|c|}{ The Test Types of Reading Exercises } \\
\hline & Essay & $\begin{array}{c}\text { True or } \\
\text { False }\end{array}$ & Matching & Short Answer & $\begin{array}{l}\text { Multiple } \\
\text { Choice }\end{array}$ & $\begin{array}{l}\text { Completion } \\
\text { Item }\end{array}$ \\
\hline $\mathbf{1}$ & Task 3 & - & - & - & - & Task 2 \\
\hline 2 & Task 2, 4 & - & - & - & - & Task 5 \\
\hline 3 & & - & - & - & - & \\
\hline 4 & $\begin{array}{c}\text { Task } 1,2,3 . \\
\text { Task } 2,4\end{array}$ & - & Task 4 & - & - & Task 3 \\
\hline 5 & Task 2, 3 & - & Task 1 & - & - & - \\
\hline 6 & Task 3 & - & - & - & - & Task 2 \\
\hline 7 & & - & - & - & - & - \\
\hline 8 & Task 1 & - & - & - & - & - \\
\hline 9 & Task 1,2 & - & - & - & - & - \\
\hline 10 & Task 2 & - & - & Task 1 & - & - \\
\hline 11 & Task 2 & - & - & Task 1 & - & - \\
\hline 12 & Task 2 & - & - & Task 3, 4 & - & - \\
\hline 13 & Task 1 & - & - & - & - & - \\
\hline 14 & Task 2 & - & - & - & - & Task 1 \\
\hline 15 & - & - & - & - & - & - \\
\hline Exercise & 19 & - & 2 & 4 & - & 5 \\
\hline Total Exercises & & & & Exercises & & \\
\hline
\end{tabular}

Based on table 3, it shows that from 4 types of reading exercises there isn't True or False and Multiple
Choice test types. Actually, many exercises includes in English course book. This research only focuses on the 
reading exercises. The analysis use checklist to find the distributions of the domain cognitive in each exercise of reading. There are six cognitive domains in the Bloom's Taxonomy, the revised edition. And, it is divided onto lower order thinking such as remember, understand, and apply; and higher order thinking such as analyze, evaluate, and create. This allow us to be able to know and to analysis the distribution of the HOTS in reading exercises. Then, table 4 explains that the distribution and percentage every skill in the HOTS in reading exercise.
Table 4. Higher Order Thinking Skill Distribution in Reading Exercise

\begin{tabular}{ccc}
\hline $\begin{array}{c}\text { Level of Higher } \\
\text { Order } \\
\text { Thinking }\end{array}$ & $\begin{array}{c}\text { No. of } \\
\text { Questions }\end{array}$ & Score \\
\hline Analyze & 33 & $33 / 171 \times 100 \%=19,3 \%$ \\
\hline Evaluate & 10 & $10 / 171 \times 100 \%=5,8 \%$ \\
\hline Create & 5 & $5 / 171 \times 100 \%=2,92 \%$ \\
\hline Total & $\mathbf{4 8}$ & $\mathbf{4 8} / \mathbf{1 7 1 \times 1 0 0 \%}=\mathbf{2 8 , 1 \%}$ \\
\hline
\end{tabular}

The table 4 shows, from 48 reading questions, 33 questions in analyze level with $19,3 \%$. Then, evaluate level obtains 10 questions with $5,8 \%$. While, for create level obtains 5 questions with 2,92\%. The table 5 show, 33 questions have the type of analyze skill. Chapter four 16 questions, chapter eight and fourteen 1 question. The next table show that the question of reading exercises belong to type of evaluate skill.

Table 5. Data of analyze skill level Questions in the English course book

\begin{tabular}{|c|c|c|}
\hline Chapter & No. & Analyze Skill level \\
\hline \multirow[t]{17}{*}{2} & 24. & When do we congratulate people? \\
\hline & 29. & Why did Ditto say it to Dita? \\
\hline & 34. & $\begin{array}{l}\text { According to the passage, could you predict what ecotourism is? Give another examples of } \\
\text { ecotourism destinations. }\end{array}$ \\
\hline & 38. & $\begin{array}{l}\text { What does the word "ex-captive" tell you about the orangutans in Camp Leakey, which is a } \\
\text { rehabilitation site for orangutans? }\end{array}$ \\
\hline & 42. & In your opinion, what is the most fascinating scene in TanjungPuting National Park? \\
\hline & 45. & How does each paragraph relate each other? \\
\hline & 46. & What tense is mostly used in this passage? \\
\hline & 50. & What did you feel when you read the word "majestically"? \\
\hline & 53. & Read the third line of paragraph two. What did you feel after reading the description? \\
\hline & 54. & What are the materials and how TajMahal was designed? \\
\hline & 55. & What is signaled by all the materials and the architecture? \\
\hline & 56. & Where was the queen actually buried? \\
\hline & 57. & When is the best moment you think to visit TajMahal? \\
\hline & 58. & What is the writer's intention in writing the essay? \\
\hline & 60. & What reaction from readers does the writer expect? \\
\hline & 62. & $\begin{array}{l}\text { After reading text } 2 \text { (TajMahal), identify the main idea of the paragraphs. Pay attention to how the } \\
\text { ideas in the text are organized. }\end{array}$ \\
\hline & 63. & $\begin{array}{l}\text { Using the following Venn diagram, try to find the similarities and differences between text } 1 \text { and text } \\
\text { 2. In what way are they similar or different? Write the similarity in the shared area }[\mathrm{B}] \text { and the } \\
\text { differences in the separate areas }[\mathrm{A}] \text { or }[\mathrm{C}] \text {. }\end{array}$ \\
\hline \multirow[t]{2}{*}{5} & 76. & $\begin{array}{l}\text { Could you figure out a place of that has similar beauty to Niagara Falls in your } \\
\text { area? Tell your classmates about the place. }\end{array}$ \\
\hline & 77. & $\begin{array}{l}\text { Read again text } 1 \text { (TanjungPuting National Park) and text } 2 \text { (TajMahal) in chapter } 4 \text {. Compare those } \\
\text { texts with the text about Niagara Falls. Find the similarities among those three texts. }\end{array}$ \\
\hline \multirow[t]{2}{*}{6} & 85. & Is there any announcement regarding to ticket sale? \\
\hline & 86. & What did Faith \& D Entertainment write in the last paragraph? \\
\hline 8 & 104. & Why do you think people like Afgan? \\
\hline \multirow[t]{3}{*}{9} & 107. & $\begin{array}{l}\text { As you know on every } 10 \text { November we all celebrate Heroes Days. Why do you think the Heroes Day } \\
\text { took that special date to commemorate our heroes' sacrifice? Discuss with your partners and come to } \\
\text { a conclusion why the date has become special. After that, read through the passage and check whether } \\
\text { your conclusion is the same as the reason stated in the text. }\end{array}$ \\
\hline & 117. & $\begin{array}{l}\text { Why do you think the date of the Battle of Surabaya is used as a momentum to commemorate our } \\
\text { hero's contribution? }\end{array}$ \\
\hline & 120. & Have you read other passage that tell about similar events? What are they? \\
\hline 11 & 140. & What effect that was given by Cut NyakDhien's marriage to Teuku Umar on the Aceh armies? \\
\hline
\end{tabular}




\begin{tabular}{cll}
\hline & 142. & How was Teuku Umar killed? \\
\cline { 3 - 3 } & 143. & $\begin{array}{l}\text { Based on the passage, what should an Acehnese woman do to respond the death of her family member } \\
\text { in a war? }\end{array}$ \\
\hline 12 & 150. & $\begin{array}{l}\text { In the story 'Issumboshi' there are words that describe the characters and the setting. Find them in the } \\
\text { story and list them below. }\end{array}$ \\
\hline 151. & $\begin{array}{l}\text { In the story there are also words that tell us what happen. These words are doing words (verbs). They } \\
\text { tell us what the characters do. Thinking verbs are verbs that describe how the characters feel or what } \\
\text { the characters think. Find the doing and thinking verbs in the story. List them in the following table. }\end{array}$ \\
\hline $\mathbf{1 4}$ & 152. & Why did Malin Kundang and his mother have to live hard? \\
\hline 153. & Show an example that MalinKundang was a diligent, strong and a healthy boy! \\
\hline
\end{tabular}

Table 6. The Questions List of Evaluate skill

\begin{tabular}{lll}
\hline Chapter & No. & Questions List of Evaluate Skill \\
\cline { 2 - 3 } & 43. & How important is the research by Dr. BiruteGaldikas? \\
\cline { 2 - 3 } & 59. & How does the writer organize his idea? \\
\hline $\mathbf{9}$ & $\begin{array}{l}\text { Reread text 1 . discover the similarities between text 1 } \\
\text { and text 2 }\end{array}$ \\
\hline 112. & Can you compare the Indonesian military power to British army at that time? \\
\hline 113. & $\begin{array}{l}\text { What made the Indonesians dare to face the British army military } \\
\text { aggression? }\end{array}$ \\
\hline 114. & Did the Indonesian lose or win the battle? Why do you think so? \\
\hline $\mathbf{1 3}$ & 115. & What that the battle the national revolution at that time? \\
\hline 14 & 119. & Do you think that the information in the text clear? \\
\hline & 169. & What is the moral of the story? \\
\hline
\end{tabular}

Table 7. The Questions List of Create skill

\begin{tabular}{ccl}
\hline Chapter & No. & \multicolumn{1}{c}{ Questions List of Create Skill } \\
\hline $\mathbf{1}$ & 1. & $\begin{array}{l}\text { After you read the passage, in the chart below, find out the main idea of each } \\
\text { paragraph, and then write the most important details in your own words }\end{array}$ \\
\hline $\mathbf{4}$ & 48. & $\begin{array}{l}\text { Rearrange the place of the main ideas in the right column to match it with the } \\
\text { purpose of each paragraph }\end{array}$ \\
\hline $\mathbf{9}$ & 78. & $\begin{array}{l}\text { After reading the text, in the chart below, identify the main ideas of the } \\
\text { paragraphs, and then write the most important details in your own words. }\end{array}$ \\
\hline $\mathbf{1 1}$ & 111. & $\begin{array}{l}\text { What caused the war? make a diagram that indicates chronologically the events } \\
\text { that led to the war. }\end{array}$ \\
\hline & $\begin{array}{l}\text { Create as many questions as you can based on the story. Use question words } \\
\text { such as who, when, where, why, how. Then, exchange your questions with a } \\
\text { classmate sitting next to you. Discuss them together. }\end{array}$ \\
\hline
\end{tabular}

From the table six, it looks the book has ten questions. The evaluate skill is the highest; in chapter 9 has 5 questions, in chapter 13 and 14 have 1 question. And the create skill, exists in the 3 skills in HOT. It shows that there are 5 from 171 questions are categorize in create skill. The table 7 . From the table 7 , it shows that the chapters which obtain create skill are chapter 1 , chapter 4 , chapter 6 , chapter 9 , and chapter 11 . There are 5 questions out of 171 questions that include in this English course book. It means, the creating, in this book has the highest level. Thus, the percentage of HOTS in this English course is $28,1 \%$ where analyze level gets $19,3 \%$ with 33 questions, evaluate level gets 5,8\% with 10 questions, and create level gets $2,9 \%$ with 5 questions out of 171 questions of reading exercise in English course book for 10th grade senior high school.
There are six types of reading exercises as stated by Heaton (2000). They are essay, short answer question, matching test, true/false reading test, multiple choice, and completion items. There are some of them distributed in the English course book.

In order to make it more clearly, see Figure 1 of the types of reading exercise distributed in that book.

Figure 1 is showed the frequency of the types of reading exercises delivered in the English Course Book for 10th grade senior high school published by Indonesia ministry of education and culture. This reading exercises was analyzed from the first until the second semester and there are 30 reading exercises from 15 chapters in this book. Related to the graph above, it shows that essay is categorized the most frequently found and distibuted in this English Course Book. It is common for reading 
exercises in order to assess the students' reading comprehension ability toward the text.

Additionally, completion item and short answer was rarely found in this English Course Book, especially for reading comprehension test. Lastly, matching exercises was also distributes in this book although only 2 exercises discovered this kind of exercise as a reading comprehension exercise. To sump up, based on the data analysis and finding above, eassy is the most type of reading exercises discovered, and there is no true false and multiple choice as a reading exercises found this book.

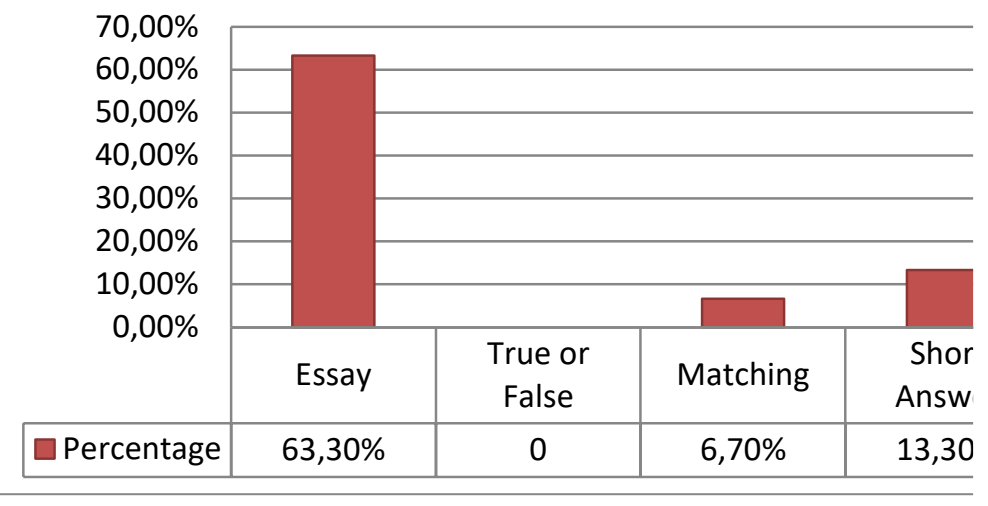

Figure 1. The Types of Reading Exercises Distributed in English course book for $10^{\text {th }}$ grade senior high school published by Indonesia ministry of education and culture

Figure 2. The Percentage of LOTS and HOTS Reading Comprehension Exercises Discovered in the Reading Exercises of English Course Book for $10^{\text {th }}$ Grade Senior High School

There are six types of cognitive process identified in revised Bloom Taxonomy published by Anderson and Krathwohl (2001). They are knowledge, comprehension, and application that noticed as a lower thinking skill and analyze, evaluate, and also create which perceived as a higher order thinking skill. Based on the finding above, all of these cognitive process found out in the types of reading exercise. Particularly, the finding of the types of cognitive process in the reading exercises of this English Course Book shown in this following Figure 2.The Figure 2 is the frequency of the types of the cognitive process recovered in the English Course Book. Knowledge is mostly noticed in the reading comprehension exercises. This level of reading comprehension questions mostly found in all chapters of the book and 73 from 171 reading comprehension questions discovered as a knowledge questions. On the other hands, this English Course Book frequently used Lower Thinking Skill in the reading comprehension questions. Then, it is followed by analysis skills which is identified as a HOTS. It means, in reading 
comprehension question, the author also considered to use this type of Higher Order Thinking Skill (HOTS) although it was noticed 36 from 171 reading comprehension questions. It has slightly comparison with comprehension questions which differ only one questions. Additionally, evaluate questions also discover in this book with total number 13 , followed by application questions where there 9 questions noticed from reading comprehension exercises. Furthermore, create questions is infrequently noticed in this English Course book. It is shown that from 171 questions detected, only 5 create questions discovered in the reading comprehension questions. Based on this explanation, it can be concluded that there were several facts found related to the distribution of LOTS and HOTS in the reading exercises. First, LOTS is frequently found in the reading comprehension questions than HOTS. Second, knowledge questions as a one of LOTS is the most frequently found in the reading comprehesion questions and it almost $50 \%$ of the reading comprehension questions are knowledge questions. Finally, HOTS is rarely discovered in this English Course Book. It can be seen from the percentage of the finding. It is only $31,6 \%$ questions of the reading comprehension questions revealed as HOTS.

\section{CONCLUSION}

Related on the research problem revealed in this article about reading exercises in English Course Book published by Indonesia Ministry of Education and Culture, the findings and discussion of the research, there are some conclusions that can be stated. The reading exercises matched with the current curriclum and learners need. It is proven from the reading exercise types revealed are varied and in accordance with the level of Senior High School Students. Four types of reading exercise noted from the course book; Essay or long-answer questions, matching tests, short-answer questions, and completion Item. On the other hands, there is no true or false test and multiplechoice tests in the English Course Book. The distribution of Higher Order Thinking Skills (HOTS) and Lower Order Thinking Skills (LOTS) become the important factor to analyze in the reading exercises in the text book. The result of this research reveal, among 171 questions revealed, 54 questions was categorized as a HOTS and 117 questions was classified as a LOTS. On the other hand, $68,4 \%$ was labeled as a LOTS. Hence, the reading exercises was dominated by LOTS. In conclusion, based on the results obtained it can be described that this book does not represent the 2013 curriculum yet which requires students to think more critically. However, in fact, books as a learning medium do not support this competency.

There are some implications related to types of reading exercises and distribution of HOTS in the English Course Book. They are: Dealing with the reading exercise types found, it can be implied that the reading exercises of this textbook have skill developed and can classify into a good textbook and available with syllabus of senior high school and relevance with curriculum 2013. Dealing with distribution of HOTS in the English Course Book, it concluded that the textbook very emphasizes on the type of analyze skill. Compared to 6 cognitive domain, it's regarded to gave a little distribution between them. Furthermore, the calculation of the ration between "analyze and evaluate skill" gets 1:3. This is implying the range still far, the textbook's author gave emphasis to the skill of analysis. It also can be stated, the distribution of the HOT in the essay reading questions is un equal, because the ratio and total score are so distingtive from the LOT skill. Hence, the HOT skill is not practiced and treated properly through essay reading exercises in the Course Book, for the creating skill presence rarely in essay reading exercises, found 5 among 171 questions.

\section{ACKNOWLEDGMENT}

I am grateful to all my colleagues for their support in compiling and completing this article. I am also grateful to the advisor who has fully supported and fully given direction, criticism and suggestions in the process of researching and completing this article especially for the constructive comments from reviewers, as well as several informants who provided the necessary information. I am responsible for all information in this article.

\section{REFERENCES}

[1] E.M. Clarke, E.A. Emerson, Design and synthesis of synchronization skeletons using branching time temporal logic, in: D. Kozen (Eds.), Workshop on Logics of Programs, Lecture Notes in Computer Science, vol. 131, Springer, Berlin, Heidelberg, 1981, pp. 52-71. DOI: https://doi.org/10.1007/BFb0025774 [2] Airasian, P. W. \& Russell, M. K. (2008). Classroom Assessment: Concepts and Applications. Boston: McGraw-Hill. 6thEd.

[3] Al-Qader, Ahmad \& Seif. 2012. "Evaluating the Higher Order Thinking Skills in Reading Exercises of English for Palestine Grade 8". Thesis: Islamic University Gaza.

[4] Bloom, B. S. (1956). Taxonomy of Educational Objectives. Ann Arbor: David McKay Company Inc.

[5] Brassell, D., Rasinski, T.. (2008). Comprehension that Works: Taking Students Beyond Ordinary Understanding to Deep Comprehension. New York: Shell Education.

[6] Brookhart, Susan M. 2010.How to Asses HigherOrder Thinking Skills in Your Classroom. Alexandria: ASCD Member Book.

[7] Brown, H. D. 2007. Principles of language teaching and learning. Pearson Education: NY.

[8] Chen, Mei-Hui. (2016). Theoretical Framework for Integrating Higher-order Thinking into L2 Speaking, Theory and Practice in Language Studies, 6(2), pp. 217-226, DOI: http://dx.doi.org/10.17507/tpls.0602.01 
[9] Connolly, M. (2000). What we think we know about critical thinking. CELE Journal, 8, Retrieved April 20, 2003, from http://www. asiau.ac.jp/english/cele/articles/Connolly_Critical-

Thinking.htm

[10] Crawley, S. J \& Merritt, K. (2000). Remediating Reading Difficulties. NewYork: McGraw-Hill. 3rd Ed.

[11] Cunningsworth, A. (1998). Choosing Your Coursebook. Oxford: Macmillan Publisher.

[12] Damanik, S. N. H. \& Zainil, Y. (2019). The analysis of reading comprehension questions in english Textbook by using higher order thinking skill at grade $x$ of SMAN 2 padang. Journal of English Language Teaching, Vol. 8. No. 1.

[13] Fisher, D. \& Frey, N. (2007). Checking for Understanding. Alexandria: ASDC.

[14] Fry, E. (2000). Skimming \& Scanning: Jamestown' Reading Improvement. Illinious:

Jamestown

[15] Grabe, W. (2009). Reading in a Second Language. New York: Cambridge University Press.

[15] Grellet, Francoise. 2010.Developing Reading Skill. Cambridge: Cambridge University Press.

[16] Harmer, Jeremy. 2007.How to Teach English. Oxford: Pearson Education. New Ed.

[17] Heaton, 2002.Writing English Language Test, London: Longman.

[18] 'Ilma, Faradina. 2018. Higher Order Thinking Skill Questions in Reading Exercises (An Analysis of Reading Exercises in Bright Course Book for the Seventh Grade of Junior High School of 2013 Curriculum, Published by Erlangga in the Year of 2016. Thesis. Walisongo State Islamic University Semarang.

[19] Igbaria, Abdul Kareem. 2013. "A Content Analysis of the WH-Questions in the EFLTextbook of Horizons. Sakhnin Academic College for TeacherEducation, Israel.

[20] Iqbal, J. 2013. A review of English textbook at secondary level in the province of Khyber Pakhtunkhwa, Pakistan. Research Journal of Educational Sciences 1(3), 1-5.

[21] Keshta, Sulaiman \& Seif, Aya. 2013. Evaluating the Higher Order Thinking Skills in Reading of English for Palestine Grade Eight. Asian Journal of Education and E-learning. Vol 1 (1).

[22] Klinger, Jenette. K. Vaughn, Sharon and Alison Boardman. 2007. Teaching Reading Comprehension to Students with Learning Difficulties. London: The Gulford Press.

[23] Linse, Caroline T. 2006.Practical English language Teaching: Young Learners. NewYork: McGraw-Hill.

[24] Marier, R. 2000. Reading Comprehension Techniques for Improving Students' Success in Extracting Useful Knowledge from Text. New Jersey: Pearson Education, Inc.
[25] Mrah, Isam. 2017. Developing Higher Order Thinking Skills: Toward a Rethinking of EFL Coursebooks in Morrocan High Schools. Journal of English Language Teaching and Linguistics. Vol 2 (3).

[26] Musial, Diann, et.al. 2009.Foundations of Meaningful Educational Assessment. New York: McGraw Hill.

[27] Ostrov, Ric. 2003. Power Reading: The Best Course on Spreading Comprehension Improvement ever Developed. North San Juan: Education Press.

[28] Partnership for 21st Century Skills. 2009. P21 framework definitions [White paper]. Retrieved August 22, 2018 from http://www.p21.org.

[29] Pratiwi, Nur. 2014. Higher Order Thinking Skill in Reading Exercise (An Analysis of Reading Exercises in Pathway to English Textbook for the Eleventh Grade of Senior High School Students). Thesis. The Syarif Hidayatullah State Islamic University Jakarta.

[30] Reed, Arthea J S., et.al. 1998.In the Classroom: In Introduction to Education. Boston: McGraw-Hill.

[31] Richards, Jack C. 2001.Curriculum Development in Language Teaching. Cambridge: Cambridge University Press.

[32] Sanavi, R. \& Tarighat, S. 2014. Critical thinking and speaking proficiency: A mixed-methodstudy. Theory and Practice in Language Studies, 79-87. doi:10.4304/tpls.4.1.79-87.

[33] Sardareh, A.S \& Saad, Mohd. R. 2013. Malaysian Primary School ESL Teachers' Questions during Assessment for Learning. English Language Teaching Journal. Vol 6 (8).

[34] Shen, Ping. 2012. A Case Study of Teacher"s Questioning and Students" Critical Thinking in College EFL Reading Classroom, International Journal of English Linguistics. Vol. 2.

[35] Suharyadi. 2014 “Exploring „Scientific Approach" in English Language Teaching",(www.teqip.com).

[36] Tankersley, Karen. 2003. The Thread of Reading: Strategies for Literary Development. Virginia: ASCD.

[37] Ur, Penny. 2009. A Course in Language Teaching: Practice and Theory. Cambridge: Cambridge University Press.

[38] Westwood, Peter. 2001. Reading and Learning Difficulties: Approaches to Teaching and Assessment. Australia: Acer Press.

[39] Wright, T. 2005. Classroom Management in Language Education. New York: Palgrave MacMillan 